\title{
Empirical Study to find the Nexus between Economic Development and Environment Degradation: Evidence from Pakistan
}

\author{
Saad Nisar ${ }^{1}$ \\ Sardar Shakeel Ahmad ${ }^{2}$ \\ Muhammad Fiaz ${ }^{3}$
}

\begin{abstract}
This research shows the relationship between environment degradation, economic development, financial development, energy consumption, electricity production and natural resource depletion by using Environmental Kuznets curve hypothesis in Pakistan with yearly data from 1976 to 2013. TheARDL bound test to co-integration and error correction model is applied to check the relationship among the variables. The results conclude that there is long run evidence of environmental Kuznets curve in Pakistan but short run evidence does not exist. Energy consumption and natural resource depletion degrade the environment quality in long run. Electricity production from hydroelectric source improves the environment quality both in long run and short run. Financial development has insignificant positive impact on environment degradation in long run and also in short run. As a policy implication we recommend that the coal power plant should be converted into natural gas power plant because natural gas power plants emit $50 \%$ less carbon dioxide (CO2) as compared to coal power plants. The government should create steps to reduce diesel engines because they discharge heavy smoke and deteriorate environment quality. Forest area must be increased in Pakistan because from 1990-2016 there is a huge fall in it because forest clean the environment quality of country and reduce the global warming which is a universal problem.
\end{abstract}

Keywords: Growth rate, energy consumption, natural resource depletion, Environmental Kuznets curve.

\section{INTRODUCTION}

\section{Background of the Study}

The huge amount of carbon dioxide emission is coming from BRIC countries because they are progressing very fast to make their economy stable. The industrial revolution started in 1970's and since then a huge increase is seen in international trade resulting into environmental degradation. The industrial sector was heavily flooded with massive use of energy and investments in the sector mounted very high. There were benefits and advantages for developing economies. They mobilized their labor and capital and reduced their barriers to attain advantages from developed states which worsened the environmental problems. The industrial revolution process is going on in developing countries which are degrading the environment quality and global climate due to heavy use of energy.(Bento and Moutinho2016).

Kuznets (1955) originally hypothesized a curve which showed the relationship between economic growth and income inequality, the Kuznets' graph shows an inverted U shaped curve between these variables. At first stage as the economic growth of a country increases

\footnotetext{
1- M.Phil Scholar at Institute of Business and Management, University of Engineering and Technology, Lahore, Pakistan, saadnisar143@gmail.com,

2- PhD Scholar at University of Gujrat, Pakistan

3- Post Doctorate fellow at The School of Management Xi'an Jiaotong University, China

JSR-MSSE

July-Dec 2017 
income inequality also increases to a turning point and after turning point the trend becomes inverted. After few decades the study of Kuznets curve changed to the environmental Kuznets curve (EKC). Environmental Kuznets curve shows the nexus between economic development and air pollution of an economy such as environmental degradation and income per capita. At first stage the environment worsens as per capita income rises until it reaches a turning point. After that point the stage of developed economies starts and at this stage with the increase of per capita income the environment improves.

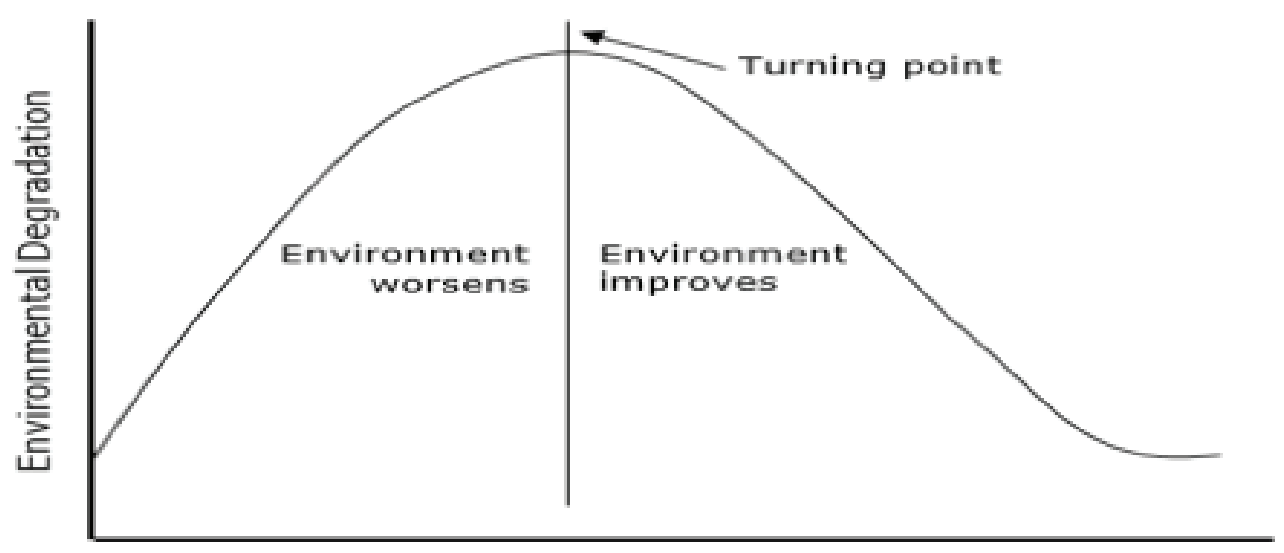

Per Capita Income

Kraft and Kraft completed their first study on EKC hypothesis in 1978 and found the relationship of energy and GNP. Their study concluded that there was strong relationship between GNP and energy and the causality running from energy consumption to economic growth but there was causality from economic growth to energy consumption.

Pakistan is facing environmental problems. Industrialization is increasing in the big cities of Pakistan which are creating adverse impact on environment quality. Karachi is one of the most pollutant cities of Pakistan due to ineffective policies against polluters. Now the citizens cannot find fresh and healthy air to breathe and they are facing noise and water problems. Industrial waste is badly affecting the underground water and it is no more drinkable in Karachi. The Environment Protection Department is silent against these wastes of industry and is not taking any action against polluters. A tremendous increase in public vehicles, absence of public transport, hike in population, deforesting and china cutting are the major problems of the citizens. Karachi is the industrial hub of Pakistan and a large number of industries result heavy emission of sulfur oxide, nitrous oxide and carbon emission which are affecting the health of general public.

Every developing and developed country wishes to have durable and stable level of economic development and economic growth rate and economic development has strong relation with environment. The rise in the temperature of the universe is a universal problem which is very injurious to the health of every living creature and it is compulsory for everyone to get knowledge about Global Warming and the reasons behind it.

The collection of many gases in air is known as green house gases and they have probity to absorb the solar temperature. The global temperature of the universe is rising due to imbalance 
of these gases. The increase in global temperature due to the increase in the green house gases is known as Global Warming. Forests balance the atmosphere of gases in air. According to the World Development Indicators report published in 1990, the area of forest in Pakistan was 25270 square kilometers but in 2015 it was recorded 14720 square kilometers. The area of forest in Pakistan is rapidly decreasing and since forests maintain the level of oxygen in air, due to reduction in the forest area the oxygen level is consistently reducing. The World Health Organization (WHO), in 2016, compiled the data of 3000 cities of the world and evaluated that pollution in air around the world had risen $8 \%$ compared to the past five years. A rapid increase in the global trade and economic development caused the pollution in air as a result of high emission of $\mathrm{CO} 2$ in air.

A massive use of natural resources and energy is not friendly for environment and emits high amount of carbon dioxide in air. The fossil fuel is the main example of natural resources; burning fossil fuel emits carbon to the atmosphere and degrades the environment quality and this leads to an extremely negative impact on environment such as floods, droughts and rising sea levels. The global consequences are already being felt more and more escalating the intensity of the storm, the reverse currents and extreme weather conditions. It is up to people to decide the future use of fossil fuel or renewable energy sources in order to change the quality of environment.

In Pakistan, the natural resources are continuously reducing. The natural gas, coal, petroleum, coal, gold, timber and forests etc. are the major natural resources in Pakistan but are depleting to change the quality of environment.

The graph of natural resource depletion is shown in figure 4.

Figure 1: Natural resource depletion from 1976-2013

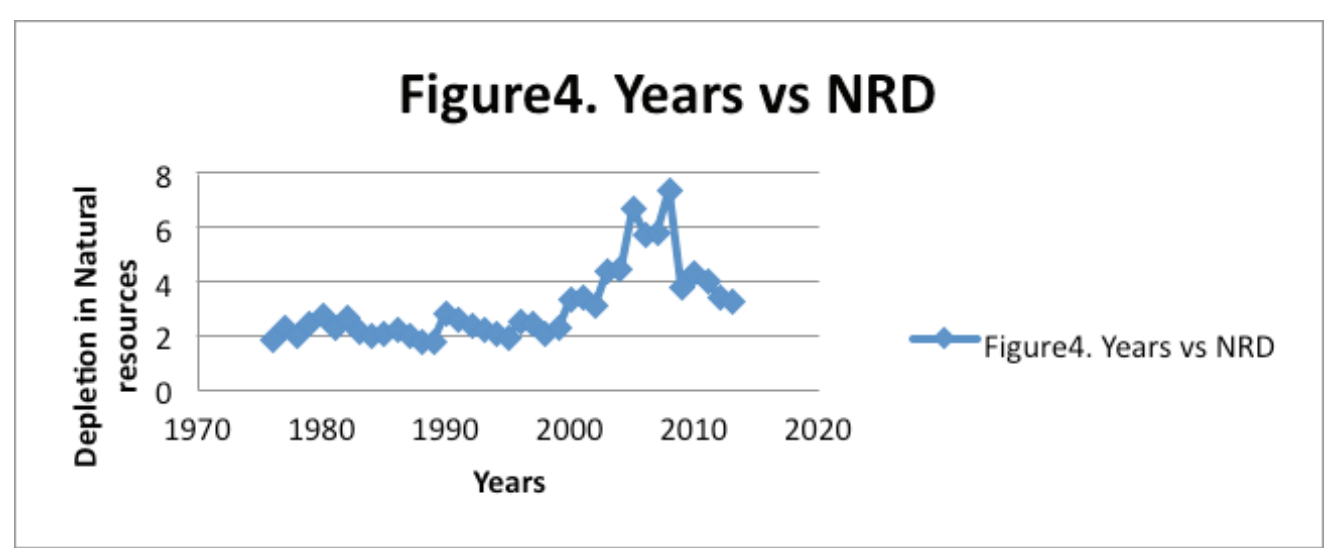

Source: World Development Indicators of Pakistan

The figure 1 is showing the depletion of natural resources (percentage of GNI). After 1998, there was a tremendous increase in depletion of natural resources. The figure is showing a positive trend overall along the period. 
Provincial Culture and Tourism Minister SharmilaFarooqui told in an interview that the depletion of natural resources at an enormous rate is the risk for biodiversity. The state of Pakistan acknowledged the care of biodiversity and it now depends on various international protocols and agreements. She also told that Pakistan is also classified among those vulnerable countries which had adverse impact of climate change.The 5000 glaciers of Pakistan are at risk consisted of droughts, heat waves, hurricanes and flooding. Pakistan faced economic loss of more than \$15billion in floods due to glacier lake outburst, floods and intrusion of salt water in the Indus Delta during 2010 - 2012. Comparing with international standard, the emission of greenhouse gases (GHG) was low in Pakistan. The GHG emission was 310 million tons equivalent to $\mathrm{CO} 2$ emission in 2008 in Pakistan which consists of nitrous oxide, carbon dioxide, Non-Methane Volatile Organic Compound, carbon monoxide by $9 \%, 54 \%, 0.3 \%$ and $0.7 \%$ respectively.

\section{Significance of the Investigation}

There are a number of researches based on environmental Kuznets curve. The most of the researchers gave important suggestion to the state to mitigate the degradation of environment. Our research is an important research because like other major problems the environment degradation is also a major problem of Pakistan. Pakistan is a growing country and growing very fast. The number of industries is increasing sharply. The oil, gas and electricity consumption is increasing at tremendous rate. With the increase in industrial sector the pollution in air is also increasing. Pollution causes diseases and damages to human life and environmental pollution is increasing the number of diseases. We are checking the major factors related to business growth and economic growth which degrade the environment quality of Pakistan. We will provide basic and major suggestion which will be helpful for Pakistan to improve its environment quality.

\section{LITERATURE REVIEW}

Different authors have different point of view about the relationship between per capita GDP and environmental degradation.

Acharyya (2009) found the impact of FDI inflow on environment problem and he also found the impact of FDI inflow on carbon emission in India. He developed two models and applied co-integration analysis for long run and found that FDI has strong positive impact on GDP growth rate and it also has strong positive impact on environmental degradation.

Ahmed and Long (2013) analyzed experimental investigation of carbon dioxide emission in Pakistan and checked environmental Kuznets curve (EKC) hypothesis. They used GDP per capita, GDP per capita square, trade openness ratio and population growth as independent variables and $\mathrm{CO} 2$ emission is taken as dependent variable. They used time series data from 1971 to 2008. They applied co-integration analysis with ARDL bound testing approach and found that in short run EKC was not supported but the evidence of long run Environmental Kuznets curve were supported in Pakistan. They also found that there was clear powerful but positive relationship between energy consumption and environmental degradation. Population growth does have strong impact on $\mathrm{CO} 2$ emission but its impact in unidirectional. In short run there was no strong relationship among the variables except energy consumption and trade openness had negative relationship with environment degradation in short run but not in long run. 
Alege, Adediran and Ogundipe (2016) examined the connection of energy use with environmental degradation in Nigeria. He used GDP per capita, fossil fuel, energy consumption, human capital (proxied by school enrollment), electricity power consumption as independent variables and $\mathrm{CO} 2$ emission as dependent variable. They applied Johensen co-integration test by using data from 1970 to 2013 . They found that fossil fuel and electricity consumption enhances the environmental degradation but fossil fuel had significant causal link with $\mathrm{CO} 2$ emission. The relationship of per capita GDP and per capita GDP2 with carbon dioxide emission was negative. So they refute that EKC is happening in Nigeria.

Bhattacharya, Lean and Bhattacharya (2014) found the impact of economic growth and coal demand on environmental degradation in India by collecting the data from 1980 to 2010 . They used three models in research; applied ARDL test to co-integration and found that there was one way nexus between per capita gross domestic product and consumption of coal. The coal consumption had positive relationship with per capita gross domestic product. They also found two way relationships between environment degradation and coal consumption.

Bozkurt and Akan (2014) analyzed and checked the link among energy use, economic development and environment degradation. They applied Josensen co-integration analysis to find the predictive values of independent variables. The results informed that the relationship between economic development and energy consumption was straight clear positive. The outcomes from results expressed that the association among carbon dioxide emission and economic development was unfriendly and adverse.

Chen and Huang (2013) investigated the presence of EKC in Next eleven countries and found inverted U shaped curve between carbon emission and per capita GDP. They also found bidirectional causality between $\mathrm{CO} 2$ emission and electric power consumption.

Dasgupta et al. (2001) and Sadorsky (2010) told that financial development increases the carbon emission in developing countries. They both used panel data of developing countries and told that financial development increases the carbon emission because of the following reasons. First, financial development increases the financial channels optimize assets liability structure, generating risk and will cease to installation of new plants and systems then the energy consumption will increase and then carbon emission will increase. Secondly, financial development increases the foreign direct investment then economic development will increase which increase the carbon emission in these countries.

Farhani, Shahbaz and Ozturk (2014) found the impact of industrial production on $\mathrm{CO} 2$ emission in china and India. They applied VECM test, Granger causality test and Bayer-Hank cointegration test to find the relation between industrial production and environmental quality. They concluded that there existed an U shaped curve in case of china but in case of India there existed an inverted $\mathrm{U}$ shaped curve between industrial production and $\mathrm{CO} 2$ emission.

Govindaraju and Tang (2013) analyzed the nexus the relationship between coal consumption, per capita gross domestic product and environment quality in two countries china and India. They applied Granger causality test and Rebust techniques of co-integration to find the nexus between the variables. The results revealed that variables were coitegrated in china but not in India. There was long run relationship between the coal consumption, gross domestic product and carbon dioxide emission in china but not in India. In India there was short run causality detected for the period of 1965-2009. 
Grossman and Krueger (1991) found the relationship between air pollution and capita GDP. They also tested the relationship of Mexico exports in US with environmental degradation. They collected the data of urban areas from 42 countries and found an inverted $U$ shaped curve existed between per capita GDP and air pollution. In section 2 they found that there is positive relation of US imports from Mexico and Environmental degradation.Grossman and Krueger (1995) collected the panel data from GEMS and applied GLS test for estimation. They concluded that GDP per capita deteriorates the environmental quality at initial level but improves environmental quality at high level.

Halicioglu (2009) checked the evidence of environmental Kuznets curve in turkey. He applied ARDL test and co-integration test to check the evidence but results showed that there was some evidence of Environmental Kuznets Curve in Turkey. GDP has strong positive relation with $\mathrm{CO} 2$ emission and GDP2 has weak negative impact on CO2 emission. Energy consumption contributed the environmental degradation but foreign trade contributed at low level.

Haq, Zhu and Shafiq (2016) investigated the EKC for carbon emission in Morocco. He also checked the impact of energy consumption and trade openness on environmental degradation from the period 1971 to 2011. They applied johensencointegration causality test to check the nexus between these variable. Long run estimate does not provide the evidence of EKC in Morocco but short run estimates provide us the evidence of presence of EKC. Furthermore energy consumption has positive link with environmental degradation but trade openness is friendly with environment improvement.

Haseeb and Azam (2015) explored the nexus between CO2 emission and economic growth in Pakistan. For this purpose they gathered the data from 1975 to 2013. They applied johansen co-integration and Vector error correction model technique to find the estimated values. The results clearly revealed that GDP growth and energy consumption both escalates the $\mathrm{CO} 2$ emission which hikes environmental problem in Pakistan.

Jalil and Feridun (2011) investigated checked the evidence of Environmental Kuznets curve hypothesis EKC in china. They also tested the domination of financial development and use of energy on carbon dioxide emission. There was long run relationship existed in china mean that financial development, energy consumption and $\mathrm{CO} 2$ emission has long run nexus among them. The contact between emission of carbon dioxide and financial development was clear positive which means that an escalation in financial development degrades the quality of environment in china and researchers also found that in china there existed environmental Kuznets curve hypothesis.

Kuznets (1955) originally hypothesized and established a new theory. He described the relationship of income inequality and income per capita. He told that there exists an inverted $\mathrm{U}$ shaped curve between these variables.

Machado (2000) found the positive relation between international trade and $\mathrm{CO} 2$ emission in Brazil.MARTINEZ and BENGOCHEA (2003) investigated the presence of Environmental Kuznets curve in Latin- American countries by using the panel data 1975-1998. They concluded that there exists a heterogeneous relationship between economic growth and environmental degradation in these countries.

Monserrate, Alban and Vera (2016) evaluated long run existence of EKC in Ecuador by using 
data from 1971 to 2011. They applied cointegration analysis and error correction model. They found the expected sign of their independent variables for Ecuador means the presence of EKC in that country. Moreover energy use have positive and significant link with $\mathrm{CO} 2$ emission which increase the pollution.

Nasir and Rehman (2010) estimated the EKC in Pakistan. For this purpose they collected the data from 1972 to 2008. They applied Johansen co-integration causality test for short run and long run estimation. The results revealed only long run EKC for Pakistan. They checked the influence trade openness and use of energy on emission of $\mathrm{CO} 2$. The estimation reveals that energy consumption increases the pollution by increasing $\mathrm{CO} 2$ emission but trade openness is friendly with environment improvement.

Shahbaz, Ahmad and Chaudhary (2008) checked the major determinants of economic growth of Pakistan. He used credit to private sector as share of GDP proxy financial development, FDI, Trade openness and annual inflationary remittance inflow are taken as independent variables and GDP per capita is taken as dependent variable. ARDL and ECM tests are applied and the results told that financial development, FDI, remittance inflow has positive but significant relation with economic growth and high inflation and trade openness slow down the economic growth short run and long run but their relation were insignificant.

Shahbaz, Lean and Shabbir (2012) examined the communication among emission of carbon dioxide, use of energy, trade openness and per capita gross domestic product in Pakistan over the period 1971 to 2009. They applied Granger causality approach. The result suggested that long run environmental Kuznets curve existed in Pakistan but short run results did not support the EKC hypothesis because results were insignificant. The communication among emission of carbon dioxide and use of energy was vigorous positive and significant. The relationship between trade openness and carbon dioxide was negative in long run mean it improved the quality of environment but in short run it had insignificant impact on $\mathrm{CO} 2$ emission.

Tamazian et al. (2009) explored the impact of economic development and financial development on CO2 emission. They used pannel data of Bric countries from 1992 to 2004. GDP, industry share, R\&D, financial liberalization, stock market value, FDI are taken as independent variables. They applied standard reduced form modelling approach and controlling for country specific unobserved hetrogenity tests were applied to check the impact of these independent variables on $\mathrm{CO} 2$ emission. GDP and industry share has positive and significant impact on $\mathrm{CO} 2$ emission. Reseach and development and FDI has weak positive relationship with $\mathrm{CO} 2$ emission. Financial liberalization declined by $0.025 \%$ with $1 \%$ increase in $\mathrm{CO} 2$ emission.

Zambrano et al. (2016) explored the relationship between economic growth and environmental degradation for Brazil. They used the data from 1971 to 2011 to found the nexus. They used GDP per capita, GDP per capita square, electricity production and energy use as independent variables and $\mathrm{CO} 2$ emission as dependent variable. They applied ARDL approach and Vector error correction Granger causality test to find predictive values of independent variables. Long run estimates provide EKC theory in Brazil but short run analysis did not provide the evidence of EKC theory. They found that energy use has positive caused link with $\mathrm{CO} 2$ emission and electricity production has negative nexus with $\mathrm{CO} 2$ emission. In long run GDP per capita has positive link with $\mathrm{CO} 2$ emission and GDP per capita square has negative relation with $\mathrm{CO} 2$ 
emission but in short run GDP per capita has negative link with CO2 emission and GDP per capita square has positive nexus with $\mathrm{CO} 2$ emission which does provide evidence of EKC theory in short run.Johansson et al. (2017) found the impact on environment if we change communication from car to bicycle. The analysis showed that there would be a large amount of reduction in environment degradation if we change our communication from car to bicycle because the study indicated that the reduction in the cars around 111,000 resulted low level of emission and then the environment quality would improve.

This paper follows the researches of Halicioglu (2009) who found energy consumption enhances the environment degradation in Turkey.Zambrano et al. (2016) who found that electricity production from hydroelectric source clears the environment quality but energy consumption degrades the environment quality in Brazil Jalil and Faridun (2011) who found that financial development enhances the environment degradation in China. Our research is different from them because we developed a new modelunder environmental Kuznets hypothesis and our contribution in this research is that we are checking the impact of natural resource depletion on environment in Pakistan.

\section{Model}

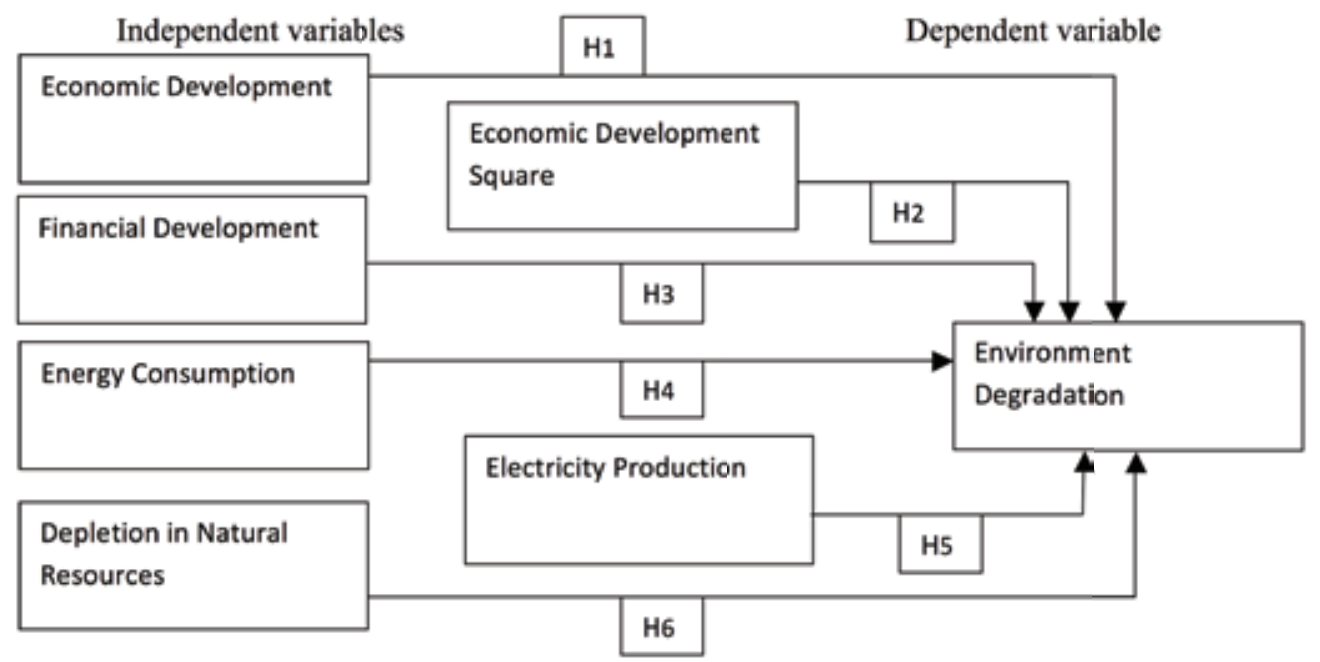

The model is clearly showing one dependent variable environment degradation and six independent variables as mentioned in the above model.

\section{Research Methodology}

This design is chosen to ensure that the most relevant information needed is available as quickly as possible and within the long and short period of time. It also ensures the accuracy and reliability of results. To analyze and test the theoretical model, different techniques are used. 


\section{Data Source}

Data related to Pakistan, CO2 emission, economic development, financial development, energy consumption, electricity production from hydroelectric source and natural resources depletion will be used from World Bank Indicators (WDI) of Pakistan.

\section{Sample size:}

Secondary time series data of Pakistan from 1976-2013 will be used in this research.

\section{Descriptive Statistic}

Descriptive statistic of the following data is as follow.

\begin{tabular}{lcccrrrr}
\hline \multicolumn{7}{l}{ Table No.1 Descriptive statistic } \\
\hline & CO2EMISSION & GDP & GDP2 & FINANCIAL & ENERGYC... & ELECTRICITY & NATURALR... \\
Mean & 1.127459 & 469.9184 & 293311.1 & 24.59812 & 281.9983 & 42.77835 & 2.910115 \\
Median & 1.144832 & 410.8303 & 168781.5 & 24.59728 & 297.5747 & 43.84871 & 2.375923 \\
Maximum & 1.303639 & 1230.815 & 1514907. & 29.78608 & 488.5635 & 60.13737 & 7.438441 \\
Minimum & 0.920942 & 100.2960 & 10059.28 & 18.12633 & 91.03172 & 25.24223 & 0.620392 \\
Std. Dev. & 0.121831 & 272.5803 & 351607.5 & 2.693373 & 132.8627 & 10.75217 & 1.464846 \\
Skewness & -0.262634 & 1.155560 & 1.948176 & -0.102580 & -0.026745 & -0.003775 & 1.418232 \\
Kurtosis & 1.675109 & 3.701246 & 5.955429 & 2.742845 & 1.579611 & 1.617903 & 4.789252 \\
\hline
\end{tabular}

\section{Unit Root Test}

Augmented Dickey-Fuller testwill be used to find the stationary level of the variables at level and first difference.

Table No. 2 Augmented Dickey-Fuller test

\begin{tabular}{llll}
\hline Variables & Level & First difference & Conclusion \\
\hline lco2 & -1.380 & $-8.326^{* * *}$ & $\mathrm{I}(1)$ \\
lgdp & -0.066 & $-5.423^{* * *}$ & $\mathrm{I}(1)$ \\
lgdp2 & -0.5224 & $-5.209^{* * *}$ & $\mathrm{I}(1)$ \\
lfd & -3.342 & $-5.317^{* * *}$ & $\mathrm{I}(1)$ \\
lec & -2.079 & $-5.118^{* * *}$ & $\mathrm{I}(1)$ \\
lep & -0.838 & $-7.526^{* * *}$ & $\mathrm{I}(1)$ \\
lnrd & $-3.22 * * *$ & $-7.410^{* * *}$ & $\mathrm{I}(0), \mathrm{I}(1)$ \\
\hline
\end{tabular}

Note: The variables with level and first difference reject the null hypothesis of non stationary of variables at $5 \%$ level of significance. $* * *$ sign shows the significant value of probability. 


\section{Equation}

$\mathrm{END}=\mathrm{f}(\mathrm{ED}, \mathrm{ED} 2, \mathrm{FD}, \mathrm{EC}, \mathrm{EP}, \mathrm{NRD})$

We will estimate the following model

$\mathrm{END}=\beta 0+\beta 1 \mathrm{ED}+\beta 2 \mathrm{ED} 2+\beta 3 \mathrm{FD}+\beta 4 \mathrm{EC}+\beta 5 \mathrm{EP}+\beta 6 \mathrm{NRD}$

Where,

END $=$ Environment Degradation

$\mathrm{ED}=$ Economic Development

$\mathrm{ED} 2=$ Economic Development Square

FD = Financial Development

$\mathrm{EC}=$ Energy Consumption

EP = Electricity Production from Hydroelectric source

$\mathrm{NRD}=$ Natural Resource Depletion

The ARDL representation of the carbon emission and economic growth relationship can be

$\Delta \operatorname{lnEND}=\beta 0+\beta 1 \Delta \operatorname{lnENDt}-\mathrm{i}+\beta 2 \Delta \operatorname{lnEDt}-\mathrm{i}+\beta 3 \Delta \ln E D 2 \mathrm{t}-\mathrm{i}+\beta 4 \Delta \ln \mathrm{l} D \mathrm{t}-\mathrm{i}+\beta 5 \Delta \ln \mathrm{ln} \mathrm{t}-\mathrm{i}+\beta$ $6 \Delta \operatorname{lnEPt}-\mathrm{i}+\beta 7 \Delta \operatorname{lnNRDt}-\mathrm{i}+\beta 8 \ln E D t-1+\beta 9 \operatorname{lnED} 2 \mathrm{t}-1+\beta 10 \ln F D t-1+\beta 11 \operatorname{lnECt}-1+\beta 12$ $\operatorname{lnEPt}-1+\beta 13 \operatorname{lnNRDt}-1+\varepsilon t$

In the above model, $\Delta$ is the difference operator, variables with t-i are lag variables, variables with $\mathrm{t}-1$ are long run variables, $\varepsilon$ t is error term and $\beta$ s indicate long run coefficients

The short-run causality is thus determined from the ARDL model;

$\Delta \mathrm{END}=\psi 0+\psi 1 \Delta \operatorname{lnENDt}-\mathrm{i}+\psi 2 \Delta \operatorname{lnEDt}-\mathrm{i}+\psi 3 \Delta \ln \mathrm{ln} 2 \mathrm{t}-\mathrm{i}+\psi 4 \Delta \ln \mathrm{FDt}-\mathrm{i}+\psi 5 \Delta \ln \mathrm{ln} \mathrm{t}-\mathrm{i}+$ $\psi 6 \Delta \operatorname{lnEPt}-\mathrm{i}+\psi 7 \Delta \ln N R D t-i+\eta \mathrm{ECTt}-1+\varepsilon t$

where, $\Delta$ is the difference operator, ECT representing the error - correction term derived from the long-run cointegrating relation from the above specified ARDL models and $\eta$ is the coefficient of error correction term it should be negative and significant which corrects the disequilibrium in short run model for long run model.)

\section{Lag Selection Criterion}

Lag selection is based on automatic lag selection in Eviews 9.5.

\section{Variables used in this research:}

lnENDis the log of Environmental Degradation (Proxied by carbon dioxide emissions per capita (measured kg per 2005 US\$ of GDP), $\operatorname{lnED}$ is the log of economic development (Proxied by GDP is per capita GDP in current US\$ ), $\operatorname{lnED} 2$ is the log of per capita GDP square which shows the turning point of environment Kuznets curve which should be negative and significant, $\operatorname{lnFD}$ is the $\log$ of financial development (proxied by credit availability to private 
sector as share of GDP), $\operatorname{lnEC}$ is the log of energy consumption from electric in KWh per capita, $\operatorname{lnEP}$ is the log of electricity production from hydroelectric source, $\operatorname{lnNRD}$ is the log of natural resource depletion percentage of GNI and et stands for residual or error term.

\section{Bound Test to co-integration}

The ARDL bound test to co-integration test technique is applied developed by Pesaran and Shin (1999) to find long run relationship among the variables.

Table No. 3Testing Long run Relationship among the variables

\begin{tabular}{lll}
\hline F-statistic $=5.442599$ & $\mathrm{k}=6$ \\
\hline Critical Value Bounds & \\
\hline Significance & $\mathbf{I}(\mathbf{0})$ Bound & I(1) Bound \\
\hline $1 \%$ & 2.88 & 3.99 \\
$5 \%$ & 2.27 & 3.28 \\
$10 \%$ & 1.99 & 2.94 \\
\hline
\end{tabular}

F-statistic is 5.44 which is greater than the upper bound of 5\% significance level (lower bound 2.27 and upper bound 3.28) means that there is long run relationship running between independent variables and dependent variable.

Long run estimates based on ARDL bound test to cointegration.

Table No. 4

Dependent Variable: Ico2

\begin{tabular}{llll}
\hline Variables & Coefficient & t- values & Probability values \\
\hline lgdp & 0.416 & 3.333 & Significant \\
lgdp2 & -0.035 & -3.413 & Significant \\
lfd & 0.026 & 0.720 & Insignificant \\
lec & 0.149 & 36.178 & Significant \\
lep & -0.079 & -2.734 & Significant \\
lnrd & 0.043 & 2.53 & Significant \\
\hline Durbin Watson $=$ & 2.12 & F-Statistic $=$ & 4.21 \\
\hline
\end{tabular}


$1 \%$ increase in GDP will degrade the environment quality by $41 \% \mathrm{t}$ statistic is 3.33 which is positive and significant. $1 \%$ increase in GDP2 will improve the environment quality by $3 \%$ which is negative and significant mean that there is long run evident of environmental Kuznets curve in Pakistan. Financial development has insignificant positive impact on environmental degradation and $1 \%$ increase in financial development will degrade the environmental quality by $2 \%$ insignificantly. Energy consumption has positive strong and significant impact on environmental degradation. $1 \%$ increase in energy consumption will degrade the environment quality by $14.9 \%$. Electricity production through hydroelectric source helps to improve the environment quality which has negative significant impact on environment degradation. $1 \%$ increase in electricity production through hydroelectric source cleans the environment quality by $7.9 \%$. Natural resource depletion degrades the environment quality significantly. $1 \%$ increase in the depletion of natural resources degrade the environment by $4 \%$. If all the independent variables are neutral and there is no change in them then the environment quality of Pakistan improves significantly.

DW value is 2.12 near to 2 mean there is no auto correlation

F statistic $=4.21$ shows the goodness of fit in the model with p-value 0.0013 less than $5 \%$

The value of R2 is.609 means that 100 percent change in independent variables will change the Environment quality by $60.9 \%$.

\section{Short run estimates}

Table No.5

Dependent variable: $\Delta$ co2

\begin{tabular}{llll}
\hline Variables & Coefficients & t- values & Probability values \\
\hline$\Delta \operatorname{lgdp}$ & 0.443 & 1.76 & Insignificant \\
$\Delta \operatorname{lgdp}$ & -0.024 & -1.93 & Insignificant \\
$\Delta \mathrm{lfd}$ & 0.05 & 1.37 & Insignificant \\
$\Delta \mathrm{lec}$ & -0.04 & -0.605 & Insignificant \\
$\Delta \mathrm{lep}$ & -0.94 & -2.72 & Significant \\
$\Delta \ln r d$ & 0.05 & 4.158 & Significant \\
ECT(-1) & -1.20 & -6.40 & Significant \\
\hline
\end{tabular}

There is no short run evidence of environmental Kuznets curve in Pakistan at 5\% significant level. Electricity production through hydroelectric source helps to improve the environment quality significantly in short run as well as in long run. Natural resource depletion degrades the environment quality in short run and long run also significantly.

The value of ECT is -1.20 which is negative and highly significant which is correcting the disequilibrium in the model by the speed of $120 \%$ annually. 
Diagnostic Tests

\begin{tabular}{ll}
\hline Tests & p-valus \\
\hline LM test & 0.599 \\
JarqueBera test & 0.909 \\
ARCH test & 0.076 \\
Reset remsey test & 0.904 \\
\hline
\end{tabular}

Themodel which is used in this research has passed all the assumptions of ARDL bound test is the best model.

\section{Conclusion and Suggestion}

The results clearly argue that in long run the environmental Kuznets curve exists in Pakistan but in short run there are no evidences of environmental Kuznets curve. Pakistan is enhancing the uses of energy use from coal and building new energy resources only from coal and forest area is declining gradually. At first side it looks like that the growth rate of Pakistan is increasing and luxuries are increasing but on the other side our environment is facing all the problems and degrading.

- Government should produce electricity from hydroelectric sources because there is negative and significant impact of electricity production from hydroelectric source on environment degradation.(Zambarano et al. 2016)

- $\quad$ Deforestation and depletion in natural resources should be stopped in Pakistan because their reduction badly affects the environment quality of Pakistan. Busa (2013) found that there is positive nexus between deforestation and environment degradation.

- $\quad$ Energy consumption from coal should be decrease because it degrades the environment quality (Zambarano et al. 2016) and (Halicioglu2009).

- $\quad$ Hybrid bikes, cars, rickshaws, buses should be introduced to reduce environment degradation(Johansson et al. 2017).

\section{Stability of the Model}

Cusum and cusum square test are used to check the stability of the model. Our model is multiple regression model and is stable long run model 

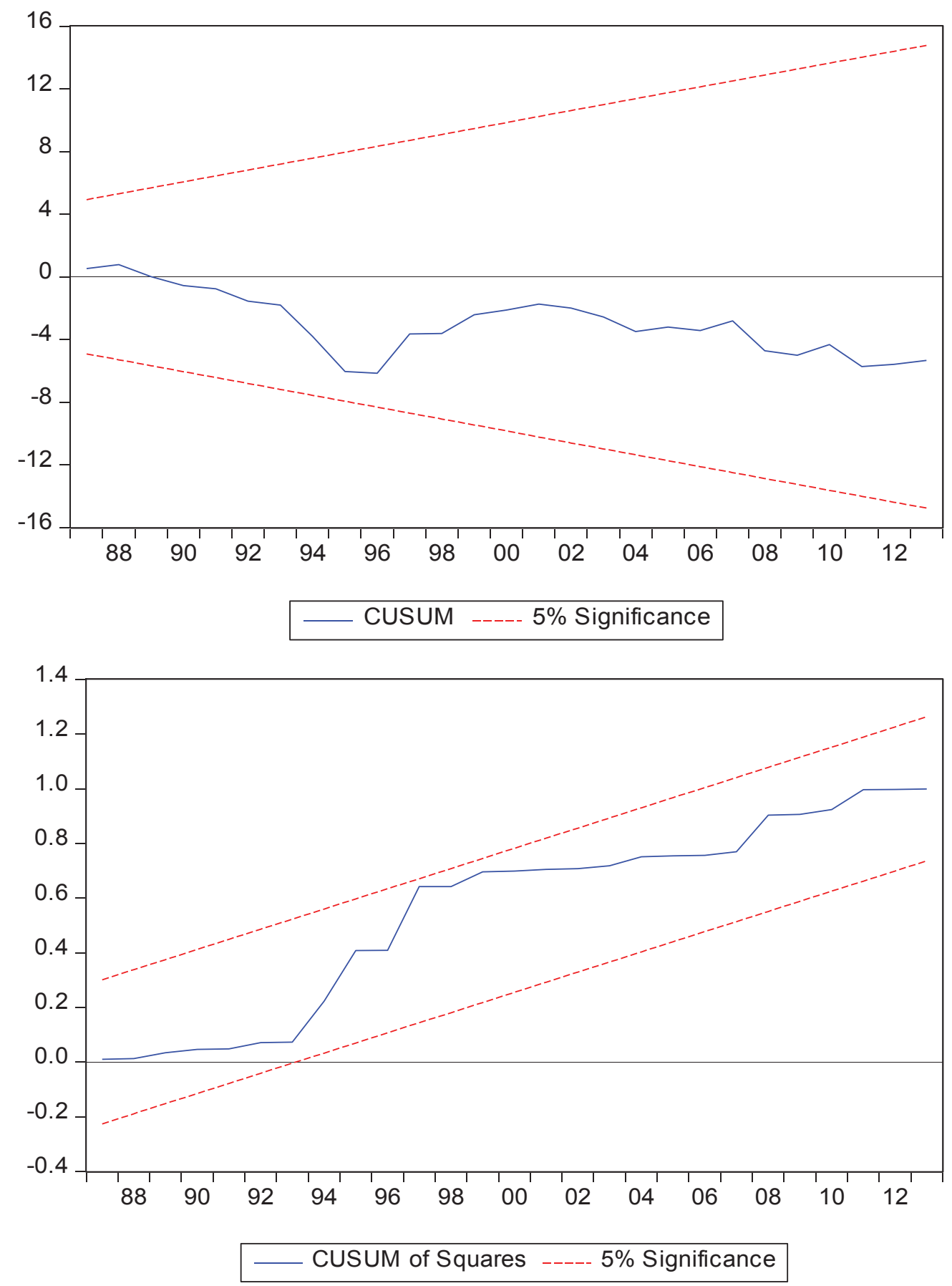

The variation line which lies within the upper and lower boundary line is showing a smooth and stable long run relationship in the model. This shows a consistent and stable pattern which emphasizes that model has a stable long run relation. 


\section{REFERENCES}

Acharyya, J. (2009). FDI, Growth and the environment: Evidence from India on $\mathrm{CO} 2$ emission during the last two decades. Journal of Economic Development, 34 (1), 43-58.

Ahmed, K., \& Long, W. (2013). An empirical analysis of CO2 emission in Pakistan Using EKC Hypothesis. Journal of International Trade Law and Policy, 12(2) , 188-200.

Bento, J. P., \& Moutinho, V. (2016). CO2 emissions, non-renewable and renewable electricity production, economic growth, and international trade in Italy. Renewable and Sustainable Energy Reviews, $55,142-155$.

Bozkurt, C., \& Akan, Y. (2014). Economic Growth, CO2 Emissions and Energy Consumption: The Turkish Case. International Journal of Energy Economics and Policy, 4(3),484-494.

Busa, J. H. (2013). Dynamite in the EKC tunnel? Inconsistencies in resource stock analysis under the environmental Kuznets curve hypothesis. Ecological Economics, 94,116-126.

Chen, J.-H., \& Huang, Y.-F. (2013). The Study of the Relationship between Carbon Dioxide (CO2) Emission and Economic Growth. Journal of International and Global Economic Studies, 6(2) , 45-61.

Dasgupta, S., Laplante, B., \& Mamingi, N. (2001). Pollution and Capital Markets in Developing Countries. Journal of Environmental Economics and Management, 42(3), 310-335.

Farhani, S., Shahbaz, M., \& Ozturk, I. (2013). Coal Consumption, Industrial Production and CO2 Emissions in China and India. IPAG working paper 2014-225,1-23.

Govindaraju, C., \& Tang, C. F. (2013). The dynamic links between CO2 emissions, economic growth and coal consumption in China and India. Applied Energy, $04,310-318$.

Grossman, G., \& Krueger, A. (1995). Economic Growth and the Environment. The Quarterly Journal of Economics, 110 (2) , 353-377.

Halicioglu, F. (2009). An econometric study of CO2 emissions, energy consumption, income and foreign trade in Turkey. Energy Policy, 37(3), 1156-1164.

Haq, I. u., Zhu, S., \& Shafiq, M. (2016). Empirical investigation of environmental Kuznets curve for carbon emission in Morocco. Ecological Indicators, 67, 491-496.

Haseeb, M., \& Azam, M. (2015). Energy Consumption, Economic Growth and CO2 Emission Nexus in Pakistan. Asian Journal of Applied Sciences, 1-10.

Jalil, A., \& Feridun, M. (2011). The impact of growth, energy and financial development on the environment in China: A cointegration analysis. Energy Economics, 33(2), 284-291.

Johansson, C., Lövenheim, B., Schantz, P., Wahlgren, L., Almström, P., Markstedt, A., et al. (2017). Impacts on air pollution and health by changing commuting from car to bicycle. Science of the Total Environment, 584-585, 55-63.

Kraft, J., \& Kraft, A. (1978). On the Relationship Between Energy and GNP. The Journal of Energy and Development, 401-403.

Kuznets, S. (1955). Economic growth and income inequality. The American Economic Review, 45, 1-28.

Machado, G. V. (2000). Energy Use, CO2 Emissions and Foreign Trade: An IO approach applied to the Brazilian Case. XIII International Conference on Input-Output Techniques, 21-25.

Martinez-Zarzoso, I., \& Bengochea-Morancho, A. (2003). Testingfor an Environmental Kuznetscurvein Latin-Americancountries. Revista de analysis Economico, 18 (1), 3-26. 
Nasir, M., \& Rehman, F. U. (2011). Environmental Kuznets Curve for carbon emissions in Pakistan:An empirical investigation. Energy Policy, 39 , 1857-1864.

Pesaran, M. H., Shin, Y., \& Smith, R. J. (1999). Bounds Testing Approaches to the Analysis of Long Run Relationship. Discussion Paper Series, 42 (pp. 1-42). Edinburgh: Edinburgh School of Economics.

Sadorsky, P. (2010). The impact of financial development on energy consumption in emerging economies. Energy Policy, 38 (5), 2528-2535.

Samargandi, N., Fidrmuc, J., \& Ghosh, S. (2015). Is the Relationship Between Financial Development and Economic Growth Monotonic? Evidence from a Sample of Middle-Income Countries. World Development, 68, 66-81.

Schmalensee, R., Stoker, T. M., \& Judson, R. A. (1998). World Carbon Dioxide Emissions: 1950-2050. The Review of Economics and Statistics, 80 (1), 15-27.

Shahbaz, M., Ahmad, K., \& Chaudhary, A. R. (2008). Economic Growth and its Determinants in Pakistan. The Pakistan Development Review, 1-18.

Shahbaz, M., Lean, H. H., \& Shabbir, M. S. (2012). Environmental Kuznets Curve hypothesis in Pakistan: Cointegration and Granger causality. Renewable and Sustainable Energy Reviews, 16, 2947-2953.

Tamazian, A., Chousa, J. P., \& Vadlamannati, K. C. (2009). Does higher economic and financial development lead to environmental degradation: Evidence from BRIC countries. Energy Policy, 37 , 246-253.

Zambrano-Monserrate, M. A., García-Albán, F. F., \& Henk-Vera, K. A. (2016). Bounds Testing Approach to Analyze the Existence of an Environmental Kuznets Curve in Ecuador. International Journal of Energy Economics and Policy, 6(2), 159-166.

Zambrano-Monserrate, M. A., Valverde-Bajaña, I., Aguilar-Bohórquez, J., \& MendozaJiménez, M. (2016). Relationship Between Economic Growth and Environmental Degradation: Is there an Environmental Evidence of Kuznets Curve for Brazil? International Journal of Energy Economics and Policy, 6(2) , 208-216. 